\title{
Ut av Norge for å bli bedre
}

Hva er det som kjennetegner Tidsskriftet? Ofte tenker man kanskje at det er valg av saker og vinklinger som gir en publikasjon et særpreg. Men viktigere enn det er de redaksjonelle standarder som settes og prosedyrene som følges. Slike er ofte usynlige for leserne og brysomme for dem som forsøker å få noe publisert. De er likevel helt avgjørende for publikasjonens identitet, kvalitet og troverdighet (1). Tidsskriftet følger internasjonale publiseringsetiske retningslinjer for vitenskapelige tidsskrifter, bl.a. retningslinjene fra The International Committee of Medical Journal Editors (ICMJE, Vancouver-gruppen) og The Committee on Publication Ethics (COPE) $(2,3)$. Det er kanskje mindre kjent at Tidsskriftet er medlem av Council of Science Editors (CSE).

CSEs formål er å fremme kvaliteten på formidlingen av vitenskapelige resultater (4). Organisasjonen ble opprettet under navnet The Council of Biology Editors i 1957 av National Science Foundation og The American Institute of Biological Sciences. Navnet ble endret til Council of Science Editors i 2000 for å dekke organisasjonens voksende medlemsmasse. Flertallet av medlemstidsskriftene er amerikanske og befinner seg innenfor den naturvitenskapelige disiplin, men også andre fagfelter er representert. Blant de over 650 medlemmene kan nevnes tidsskrifter som Nature, Harvard Business Review, Nederlands Tjidschrift voor Geneeskunde (det nederlandske legetidsskriftet) og Emirates Medical Journal. Så godt som alle de store medisinske tidsskriftene er med, deriblant de «fem store»: JAMA, The Lancet, Annals of Internal Medicine, $B M J$ og New England Journal of Medicine. Mange av presidentene i Council of Science Editors er rekruttert fra de medisinske tidsskriftene. I de senere år har både Lancet-redaktør Richard Horton og redaktør Anne Marusic fra Croatian Medical Journal vært presidenter.

CSE utgir flere publikasjoner. I tillegg til godt oppdaterte nettsider publiseres medlemsbladet Science Editor annenhver måned. Dessuten utgis The CSE manual for authors, editors, and publishers (5), som setter den redaksjonelle standard for mange tidsskrifter. Der beskrives eksempelvis ulike referansesystemer.

Den viktigste aktiviteten i organisasjonen er likevel den årlige konferansen, der bakteppet i programmet alltid er redaksjonelle prosesser i vitenskapelige tidsskrifter, f.eks. fagfellevurdering og spørsmål knyttet til interessekonflikter og opphavsrettigheter. Tidsskriftet har vært representert på konferansen flere ganger. Dette har gitt faglig inspirasjon og ideer til hvordan Tidsskriftet kan fornyes, forbedres og oppdateres. Deltakelsen er en viktig del av Tidsskriftets kvalitetskontroll. Er vår redaksjonelle kurs og våre standarder på linje med andre vitenskapelige tidsskrifters? Gjennom aktiv deltakelse er Tidsskriftet i tillegg med på å sette og videreutvikle gode vitenskapelige standarder for publisering.
Et satsingsområde i organisasjonen er utdeling av stipend til tidsskriftkolleger i u-land. I 2009 fikk fem redaktører en sum. Redaksjonen i noen av disse tidsskriftene, først og fremst fra Afrika, får dekket reise til og opphold på konferansen. For noen fungerer deltakelsen som oppstarten for et tidsskrift, for andre er det en oppdatering.

Den årlige konferansen holdes i USA og varer en kort uke. Den har et par hundre deltakere - representanter for alt fra de største tidsskriftene til spesialtidsskrifter med et par utgivelser i året. I dagene forut for konferansen arrangeres kurs for redaksjonelt ansatte (redaktører, manusredaktører, webansatte og redaksjonssjefer). Disse kursene er praktisk lagt opp, og deltakerne deler erfaringer og utfordringer på tvers av disipliner. I løpet av konferansen presenteres resultater fra tidsskriftenes egne forskningsprosjekter med problemstillinger som hvordan man kan korte ned tiden fra et manus blir levert inn til det er ferdig trykt, hvordan forfattere skal få informasjon om hva som kreves av dem og om tidsskriftenes forfatterveiledninger blir lest. På konferansen kan man velge mellom en mengde parallellsesjoner om ulike temaer - alt fra hvordan man kan gjøre publiseringen mer miljøvennlig, digitalisering av tidsskriftene, god tekst- og bildepresentasjon, hvordan man kan avsløre juks, kommunikasjon ut mot mediene, hvordan vitenskapelig stoff kan bli interessant og forståelig for legmannen til tips om gode Internett-ressurser. Vi blir bevisst på om vi når frem - og hvordan vi skal nå frem - til målgruppen.

På noen felter overlapper CSE andre internasjonale organisasjoner som Tidsskriftet er medlem av, f.eks. Committee on Publication Ethics (COPE) og Vancouver-gruppen (ICMJE). Tilsynelatende kan det virke rotete og uklart at flere arbeider innenfor samme område, men medlemsmassen og arbeidsmåten er forskjellig i de ulike organisasjonene. Mens ICMJE og COPE vektlegger publiseringsetikk og veiledning av redaktører og forfattere, er CSEs satsingsområde kursing i redaksjonelt arbeid. Tidsskriftet har nytt meget godt av nettopp dette.

\section{Anne Ringnes \\ anne.ringnes@legeforeningen.no}

Anne Ringnes (f. 1970) er redaksjonssjef i Tidsskrift for Den norske legeforening og medlem av programkomiteen for Council of Science Editors-konferansen i 2010, der temaet er The changing climate of scientific publishing: the heat is on

Litteratur

1. Haug C. Redaksjonelle valg og publikasjoners profil. Tidsskr Nor Legeforen 2008; 128: 807

2. Committee on Publication Ethics. http: //publicationethics.org (8.10.2009).

3. International Committee of Medical Journal Editors. www.icmje.org (8.10.2009).

4. Council of Science Editors. www. councilscienceeditors.org (8.10.2009).

5. Style Manual Committee. The CSE manual for authors, editors, and publishers. 7. utg. Reston, VA: Council of Science Editors, 2006. 